\title{
The Relationship between Emotional Intelligence and Willingness to Communicate among EFL Learners
}

\author{
Omid Tabatabaei \\ Department of English, Najafabad Branch, Islamic Azad University, Isfahan, Najafabad, Iran \\ E-mail: tabatabaeiomid@yahoo.com \\ Maryam Jamshidifar (Corresponding author) \\ Department of English, Najafabad Branch, Islamic Azad University, Isfahan, Najafabad, Iran \\ E-mail: maryam_jamshidi60@yahoo.com
}

Received: October 6, 2013 Accepted: November 28, 2013 Published: November 30, 2013

doi:10.5296/ijele.v2i1.4650 URL: http://dx.doi.org/10.5296/ijele.v2i1.4650

\begin{abstract}
The primary goal of this investigation was to explore the existence of any possible relationship between willingness to communicate (WTC) and emotional intelligence (EI) among 60 EFL learners. The data for the research were gathered using WTC and EI questionnaires which were presented in the participants' native language. The modified version of likert-type WTC questionnaire developed by MacIntyre, Baker, Clement, and Conrod (2001) was employed to assess the participants' degree of WTC. Students' EI was measured via a ninty-item Emotional Intelligence Inventory (EQ-i). The findings revealed that the EI profile of learners has a significant correlation with their willingness to participate in L2 communication and that the link between EI and WTC has been affected by gender. In general, as learners' EI increased, so did their willingness to use the L2 in class. The results of the present study can encourage authorities and EFL teachers to incorporate skills and abilities associated with EI in their curriculum and classroom activities.
\end{abstract}

Keywords: willingness to communicate, emotional intelligence, EFL learner

\section{Introduction}

In recent years, there has been a considerable amount of attraction in individual differences (ID) among learners in foreign language learning process. Learners bring to the language learning situation a wide spectrum of individual differences that influence the learning rate and the ultimate learning results. WTC and EI as two important concepts of ID can predict L2 
learning success. Goleman (1995, cited in Brown, 2007) suggests that EI is intelligence in its own right. He also explains that emotional mind is pretty quicker than reasonable mind, without the hesitation of thinking what to do. The second concept is known as the Willingness to Communicate (WTC), pioneered by McCroskey and Baer (1985), which according to MacDonald, Clement, and MacIntyre (2003), deals with the learners' psychological readiness to initiate communication. There are decades of research on emotional intelligence and WTC, however, these theoretical concepts have not been combined in research. Therefore, this study has the propensity to fill the gap in literature. In fact, the aim of this study is to investigate the relationship between English language students' EI and their WTC. The findings of this study can be of valuable help to those who seek to affect WTC through pedagogical intervention.

Contemporary second language (L2) pedagogy has attached great importance to communicative interaction in class with a view to developing learners' communicative competence. Individual learners, however, are not always willing to attempt L2 communication. Willingness to communicate (WTC) in an L2, which is an individual difference factor perceived to facilitate L2 acquisition, has been extensively studied in recent years (MacIntyre, 2007; MacIntyre, DÖrnyei, Clément, \& Noels, 1998; Yashima, 2002). Many studies have been carried out to explore L2 WTC in relation to various ID variables such as personality, self-confidence, attitudes, and motivation (MacIntyre \& Charos, 1996; Yashima, 2002), but despite the rich findings from previous research, however, little effort has been devoted to studying L2 WTC in conjunction with EI. Researcher's aim is to explore the role of a person's EI in shaping his/her willingness to have interpersonal communication with others.

\section{Willingness to Communicate}

In an effort to explain the interaction among affective variables in influencing the success of SLA, language researchers have conceptualized WTC (willingness to communicate), which is identified as an individual's intention to initiate communication when he/she is given an opportunity to do so (MacIntyre, 1994; MacIntyre et al., 1998; MacIntyre et al., 2001; Yashima, 2002). The theoretical concept of WTC has evolved from many language researchers' perspectives on communication behaviors and empirical studies that have tested affective variables in order to identify the constructs of WTC. Burgoon (1976) introduced "unwillingness-to-communicate" (UWTC) as a tendency to avoid oral communication in the attempt to describe the diversity in language behaviors.

By inverting the negative orientation of Burgoon's UWTC (1976) into a positive orientation, McCroskey and Baer (1985) conceptualized and introduced WTC to L1 language education in order to explain individual differences in L1 communication behaviors. Eventually, MacIntyre et al. (1998) adapted the theoretical concept of WTC to explore the diversity in L2 communication behaviors (MacIntyre et al., 1998; MacIntyre et al., 2001; Yashima, 2002). Researchers in WTC have hypothesized that WTC generates individual differences in communication behaviors, which in turn produce individual differences in the attainment of language proficiency. Thus, the more willing-to-communicate language students are more 
likely to succeed in the achievement of language proficiency (Clark, 1989; MacIntyre, 1994; MacIntyre et al., 1998; MacIntyre et al., 2001; Yashima, 2002).

On the basis of theoretical perspectives and empirical studies in regard to the relationship between WTC and SLA, MacIntyre et al. (1998) conceptualized a heuristic model of WTC in L2 in order to explain the anticipated interrelations among affective variables influencing WTC. The heuristic model consists of a pyramid-shaped structure with six categories or variables called layers. In general, the heuristic model includes five basic affective variables - motivation, confidence, attitudes, communicative competence, and personalityin order to explain the interrelations of the affective variables in influencing an L2 learner's WTC in L2.

Dornyei (2003) states that many L2 learners tend to avoid L2 communication. Based on this idea Kang (2005) argues many L2 learners may not use the opportunities to learn language through authentic communication. MacIntyre et al. (1998) believe that producing WTC is a crucial component of modern language instruction. They argue that current emphasis on communicative competence may produce students capable of communication inside the classroom, but these students "may not be amenable to do so outside the classroom. Kang (2005) reports that teachers will have more active learners by making them more willing to communicate. Kang states that students with high WTC are more likely to use L2 in authentic communication and function as autonomous learners by making independent efforts to learn language. He also believes that students with high WTC will have their learning opportunities and become involved in learning activities both inside and especially outside the classrooms. The importance of WTC reaches to an extent that scholars like Dornyei (2005) consider it as the "ultimate goal of instruction".

\subsection{WTC \& Studies Related to L2}

MacIntyre, Baker, Clement, and Donovan (2002) studied WTC, perceived competence, French anxiety, integrativeness and motivation in terms of sex and age among 7th, 8th and 9th grade junior high school students in a French immersion program. The results indicate that girls are more willing to communicate than boys, students in grade 8 and 9 are more willing than students at grade 7, and overall students WTC is higher in English (their mother tongue) than in French. In addition, the results showed that students at grade 8 and 9 communicate more frequently than students in grade 7; however, students' motivation declines from grade 7 to grade 8 and 9. Furthermore, it is observed that WTC, language anxiety, communication frequency, and perceived competence are correlated which suggests that students who are motivated tend to be more willing to communicate, have higher perceived competence, have lower French anxiety and communicate more frequently.

Yashima (2002) tested her structural model, which was also developed according to the socio-educational and WTC models in Japan. Unlike the previous studies, this study applied the WTC model in the English as a foreign language (EFL) context. Another novel aspect of her study is that she assessed students' attitudes toward the international community, rather than their attitude toward the native speaker group. The structural equation model, which she tested, indicated a relation between WTC and L2 self-confidence and international posture. 
Furthermore, she found that motivation affects self-confidence and proficiency in English. There was also a relationship between international posture and motivation.

\section{The Theory of Emotional Intelligences}

According to Goleman (1995) success depends on several intelligences and on the control of emotion .Specifically, he stressed that intelligence (IQ) alone is no more the measure of success. According to him intelligent account for only $20 \%$ of the total success, and the rest goes for Emotional and Social intelligences. Abisamra (2000) then queried that if this is found to be so, why the trainers don't begin to teach its components (i.e., emotional intelligence) to students at schools? He then concluded that if emotional intelligence affects student achievement, then it is vital for schools to integrate it in their curricula and thereby raising the level of students' success.

According to Salovey and Mayer (1990), Emotional Intelligence is being able to track one's own and other's feelings and emotions, to discriminate among them, and to use this to guide one's thinking and actions. Again, Salovey and Mayer (1993) wrote that an emotionally intelligent person is skilled in four areas: identifying, using, understanding, and regulating emotions. Similarly, Goleman also stressed that emotional intelligence consists of five components: Knowing one's emotions (self-awareness), managing them, motivating self, recognizing emotions in others (empathy), and handling relationships.

Later on Bar-On suggested that since EI is an important element in one's life showing and predicting success, there is a dire need to measure, operationalize and quantify this construct (Bar-On,1997). He coined the term EQ for his measure. He defined EI as a collection of capabilities, competencies, and non-cognitive skills that have an effect on a person's abilities to gain success in the face of environmental pressures. In other words, he believed that EI is the ability to realize emotions and how such emotions influence interpersonal relationships (Bar-On, 2000).

\subsection{Different Components of EI}

Bar-On (2000) believed that EI is a non-cognitive intelligence which is an important factor in determining one's ability to succeed in life and get along in the world. Bar-On identified five major scales and 15 subscales which contribute to the emotional energy and self motivation required to cope with daily environmental demands and difficulties as follows:

(1) Intrapersonal: managing oneself, the ability to know one's emotions.

(a) Emotional self-awareness (the ability to be aware of, recognize, and understand one's emotions).

(b) Assertiveness (the ability to express one's feelings, beliefs, thoughts and to defend one's right).

(c) Self-regard (the ability to be aware of, understand, accept, and respect oneself).

(d) Self-actualization (the ability to realize and reach one's potential). 
(e) Independence (the ability to be self-directed and self-reliant in one's thinking and actions and to be free from emotional dependency).

(2) Interpersonal: managing relationships with others.

(a) Empathy (the ability to understand and appreciate others' feelings).

(b) Interpersonal-relationship (the ability to establish and maintain mutually satisfying relationships that are characterized by emotional closeness and intimacy and by giving and receiving affection).

(c) Social responsibility (the ability to demonstrate oneself as a cooperative, contributing and constructive member of one's social group).

(3) Adaptability: ability to adjust to change.

(a) Problem solving (the ability to effectively solve problems).

(b) Reality testing (the ability to validate one's feelings and thoughts by assessing the correspondence between what is subjectively experienced and what objectively exists).

(c) Flexibility (the ability to adjust one's feelings/thoughts to change).

(4) Stress management: controlling stress

(a) Stress tolerance (the ability to manage one's strong emotions, adverse events, and stressful conditions by positively coping with problems).

(b) Impulse control (the ability to control one's emotions and resist an impulse to act).

(5) General mood: the ability to be optimistic and positive as well as to enjoy life.

(a) Happiness (the ability to feel satisfied with life and to have fun).

(b) Optimism (the ability to look at the brighter side of life and maintain a positive attitude in the face of problems).

\subsection{EI in Language Teaching and Learning}

Investigating the roll of emotional factors in L2 learning is not something new. A number of methodologies such as Suggestopedia exist which specifically addressed emotional and psychological issues in L2 learning, some of which were motivated by krashen's claim in monitor model, specifically the part about the affective filter (pishghadam, 2009).

With regard to the roll of EQ in foreign language learning Fahim and Pishghadam (2007) explored the relationship between EQ, IQ, and verbal intelligence with the academic achievement of students majoring in English. They found that academic achievement was strongly associated with several dimensions of EI (intrapersonal, stress management, and general mood competencies). They also found that academic achievement did not correlate much with IQ, but it was strongly associated with verbal intelligence which is subsection of IQ test. Thus, this study highlights the vital role of EQ in comparison with IQ in academic success of EFL learners. 
Skourdi and Rahimi (2010) proved that there is a positive relationship between emotional intelligence and linguistic intelligence (LI), between EI \& vocabulary knowledge and between LI \& vocabulary knowledge. It was also found that EI can be a potentional predictor for LI, and vice versa. The participants in this study were 103 junior students of English at Shiraz Azad University and Shiraz state university. Standard test were used to measure the participants EI, LI and vocabulary knowledge.

\section{Purpose of the Study}

As noted earlier, much research has been conducted on EI and WTC but these theoretical concepts have not been combined in research. Therefore, this study has the propensity to fill the gap in literature. To this end, the following question was posed and investigated in this study:

1. Is there any significant relationship between EFL learners' emotional intelligence and their sense of Willingness to Communicate?

2. Does gender have any effect on the relationship between emotional intelligence and WTC?

\section{Methodology}

The participants of this research consisted of 60 (30 males; 30 females) Iranian EFL learners aged between 19 and 34 years old attending two branch of Sadr English center at intermediate level. The participants were involved in the study, based upon results of Interchange Placement Test (IPT).

The principal material consisted of two sets of self-report questionnaires: Translation version of likert-type WTC questionnaire developed by MacIntyre, Baker, Clement, and Conrod (2001) assessing the participants' WTC and ninty-item Emotional Intelligence Inventory from Bar-On (1980) assessing EI. The questionnaires were presented in Persian to the students in order to prevent any complication which might result from some of the participants' limited level of proficiency in English. In addition to, the participants were asked to fill out the age and gender parts of questionnaires.

\section{Results and Discussions}

To determine the role of learners' EI in their WTC, a Pearson product-moment correlation was applied to the data. As displayed in Table 1, the observed Pearson R of 0.657 showed a statistically significant relationship between a person's degree of willingness to communicate and his/her EI $(\mathrm{P}=.012<.05)$. This analysis revealed that emotional intelligence had significant relationship with WTC and one with higher emotional intelligence is more successful in his or her communication. 
Table 1. The correlation between EQ results \& WTC scores

\section{Correlations}

\begin{tabular}{|l|l|l|l|}
\hline & & WTC & EQ \\
\hline \multirow{5}{*}{ WTC } & Pearson Correlation & 1 & $.657^{*}$ \\
\cline { 2 - 4 } & Sig. (2-tailed) & & .012 \\
\cline { 2 - 4 } & $\mathrm{N}$ & 60 & 60 \\
\hline \multirow{2}{*}{ EQ } & Pearson Correlation & $.657^{*}$ & 1 \\
\cline { 2 - 4 } & Sig. (2-tailed) & .012 & \\
\cline { 2 - 4 } & $\mathrm{N}$ & 60 & 60 \\
\hline \multirow{2}{*}{ *. Correlation is significant at the 0.05 level (2-tailed). } \\
\hline
\end{tabular}

To find out whether gender has any relationship with WTC and EI, Pearson product-moment correlation was conducted. To this end, for each gender the correlation between EFL learner, EQ and their WTC was computed.

Table 2. The correlation between Male \& Female EFL learners' EQ and WTC scores

\section{Correlations}

\begin{tabular}{|c|c|c|c|c|}
\hline \multicolumn{3}{|l|}{ Gender } & \multirow{2}{*}{$\begin{array}{l}\text { WTC } \\
1\end{array}$} & \multirow{2}{*}{\begin{tabular}{|l} 
EQ \\
-.070
\end{tabular}} \\
\hline Male & WTC & $\begin{array}{l}\text { Pearson } \\
\text { Correlation }\end{array}$ & & \\
\hline & & Sig. (2-tailed) & & .720 \\
\hline & & $\mathrm{N}$ & 30 & 30 \\
\hline & EQ & $\begin{array}{l}\text { Pearson } \\
\text { Correlation }\end{array}$ & -.068 & 1 \\
\hline & & Sig. (2-tailed) & .720 & \\
\hline & & $\mathrm{N}$ & 30 & 30 \\
\hline \multirow[t]{6}{*}{ Female } & \multirow[t]{3}{*}{ WTC } & $\begin{array}{l}\text { Pearson } \\
\text { Correlation }\end{array}$ & 1 & $.601^{*}$ \\
\hline & & Sig. (2-tailed) & & .032 \\
\hline & & $\mathrm{N}$ & 30 & 30 \\
\hline & \multirow[t]{3}{*}{ EQ } & $\begin{array}{l}\text { Pearson } \\
\text { Correlation }\end{array}$ & $.601^{*}$ & 1 \\
\hline & & Sig. (2-tailed) & .032 & \\
\hline & & $\mathrm{N}$ & 30 & 30 \\
\hline
\end{tabular}


As demonstrated in Table 2, the correlation coefficient for female EFL learners' EQ and their WTC was 0.601 , which is statistically significant at 0.05 levels $(\mathrm{r}=0.601, \mathrm{P}=.03<.05)$. This relationship has been considered as positive. Thus, females with higher emotional intelligence are more successful in their communication. The correlation between male EFL learners' EQ \& their WTC was -0.070 , which is not statistically significant at 0.05 levels $(\mathrm{r}=-.07, \mathrm{P}=.07>.05)$. Thus the null-hypothesis as gender does not affect the relationship between his/her degree of willingness to communicate and the strength of EI is rejected. Female students' EI tends to show a higher relationship with WTC.

\section{Conclusions and Implications}

In this study, it has been assumed that EI is a factor responsible for determining an individual's degree of willingness to talk. The findings of present investigation revealed that there is a significant positive relationship between EI and WTC. The size of this correlation indicates that in most cases high levels of EI are related to high levels of learners' WTC. This is in agreement with previous theoretical and empirical studies. Rich empirical evidence exists that L2 WTC is subject to the influence of many individual difference variables, such as L2 confidence, attitudes, and motivation (Cle'ment et al., 2003; Yashima, 2002).

According to Bar-on (2000), EI develops over time and can be improved through training, programming, and therapy. In light of the obtained results and by considering Bar-on's views, we can justify exploiting and developing courses for EFL learners focusing on skills associated with EI. These courses are expected to help them manipulate their emotions appropriately, shift undesirable emotional states to more productive ones, understand the link between emotions, thoughts and actions.

The findings of this study suggest several implications for English language teaching profession. If we believe that emotional intelligence can be developed, trained and schooled (Elias, 1997), language policy makers are expected to include programs to raise emotional competencies of their learners. They should educate learners about the value of emotional competencies.

\section{References}

AbiSamra, N. (2000). The relationship between Emotional Intelligent and Academic Achievement in Eleventh Graders. Research in Education, FED.661.

Bar-On, R. (1997). The Emotional Quotient Inventory (EQ-I): Technical Manual. Multi-Health. Systems, Toronto

Bar-On, R. (2000). Emotional and social intelligence. Insights from the emotional quotient inventory (EQ-I). In: Bar-On, R., Parker, J. D. (Eds.), The Handbook of Emotional Intelligence. Jossey-Bass, San Francisco. (pp. 363-388)

Binet, A. (1905). New methods for the diagnosis of the intellectual level of subnormals. Retrieved October 1, 2007, from http://psychclassics.yorku.ca/Binet/binet1.htm 
Brown, H. D. (2007). Principals of language learning and teaching $\left(5^{\text {th }}\right.$ Ed). New York: Longman

Burgoon, J. K. (1976). The Unwillingness to communicate scale: Development and validation. Communication Monograph, 43, 60-69. http://dx.doi.org/10.1080/03637757609375916

Clark, A. J. (1989). Communication confidence and listening competence: An investigation of the relationships of willingness to communicate, communication apprehension, and receiver apprehension to comprehension of content and emotional meaning in spoken $\begin{array}{llll}\text { messages. } & \text { Communication } & \text { 237-248. }\end{array}$ http://dx.doi.org/10.1080/03634528909378760

Dörnyei, Z. (2003). Attitudes, orientations, and motivations in language learning: advances in theory, research, and applications. Language Learning, 53, 3-32. http://dx.doi.org/10.1111/1467-9922.53222

Fahim, M., \& pishghadam, R. (2007). on the Roll of emotional, psychometric and verbal intelligences in the academic achievement of university students majoring in English language. Asdian EFL journal, 9, 240-253.

Gardner, H. (1983). Frames of mind: The theory of multiple intelligences. New York, NY: Basic Books.

Goleman, D. (1995). Emotional intelligence: Why it can matter more than IQ. New York, NY: Bantam Books.

Goleman, D. (1998). Working with emotional intelligence. New York, NY: Bantam Dell.

Kang, S. (2005). Dynamic emergence of situational willingness to communicate in a second language. System, 33, 277-92. http://dx.doi.org/10.1016/j.system.2004.10.004

MacIntyre, P. D. (1994). Variables underlying willingness to communicate: a causal analysis. Communication Research Reports, 11, 135-14. http://dx.doi.org/10.1080/08824099409359951

MacIntyre, P. D. (2003). Willingness to Communicate in the Second Language: Proximal and Distal Influences. Paper presented at the 33rd annual conference of the Canadian association of Applied Linguistics, Halifax, NS, Canada.

MacIntyre, P. D. (2007). Willingness to communicate in the second language: understanding the decision to speak as a volitional process. The Modern Language Journal, 91(4), 564-576. http://dx.doi.org/10.1111/j.1540-4781.2007.00623.x

MacIntyre, P. D., Baker, S. C., Clément, R., \& Conrod, S. (2001). Willingness to communicate, social support, and language learning orientations of immersion students. Studies in Second Language Acquisition, 23, 369-388. http://dx.doi.org/10.1017/S0272263101003035

MacIntyre, P. D., Baker, S. C., Clément, R., \& Donovan, L. A. (2002). Sex and age effect on willingness to communicate, anxiety, perceived competence, and L2 motivation among junior high school French immersion students. Language Learning, 52(3), 537-564. 
http://dx.doi.org/10.1111/1467-9922.00194

MacIntyre, P. D., \& Charos, C. (1996). Personality, attitudes, and affect as predictors of second language communication. Journal of Language and Social Psychology, 15(1), 3e26.

MacIntyre, P. D., Clément, R., DÖrnyei, Z., \& Noels, K. A. (1998). Conceptualizing willingness to communicate in a L2: A situational model of L2 confidence and affiliation. Modern Language Journal, 82, 545-562. http://dx.doi.org/10.1111/j.1540-4781.1998.tb05543.x

McCroskey, J. C., \& Baer, J. E. (1985). Willingness to communicate: the construct and its measurement. Paper presented at the Annual Convention of the Speech Communication Association, Denver, CO.

Pishghadam, R. (2009). Emotional and verbal intelligence in language learning. Iranian journal of language studie, 3, 43-64.

Salovey, P., \& Mayer, J .D. (1990). Emotional Intelligence, Imagination, Cognition, and Personality, 9, 195-211.

Salovey, P., \& Mayer, J. D. (1993). The intelligence of Emotion. Intelligence, 17, 433-442. http://dx.doi.org/10.1016/0160-2896(93)90010-3

Skourdi, S., \& Rahimi, A. (2010). relationship of emotional intelligence and linguistic intelligence in acquiring vocabulary. California linguistics Notes, Volume xxxv (No.1).

Yashima, T. (2002). Willingness to communicate in a second language: The Japanese EFL context. Modern Language Journal, 86, 54-66. http://dx.doi.org/10.1111/1540-4781.00136

\section{Copyright Disclaimer}

Copyright reserved by the author(s).

This article is an open-access article distributed under the terms and conditions of the Creative Commons Attribution license (http://creativecommons.org/licenses/by/3.0/). 